S.K. Kafle MBBS DA, S.M. Malla MBBS DA, B.D. Lekhak MBBS DA

\title{
Prophylactic oral ephedrine reduces the incidence of hypoten- sion after subarachnoid block
}

The purpose of this study was to demonstrate the efficacy of oral ephedrine in preventing hypotension following subarachnoid block. Two hundred women, ASA physical status I or $I I$, undergoing lower abdominal surgery were randomly divided into two groups ( $n=100$ each). All patients were given routine oral premedication consisting of diazepam $10 \mathrm{mg}$ and ranitidine $150 \mathrm{mg}$ at bed time and at $90 \mathrm{~min}$ before surgery. In addition, Group I patients received ephedrine $30 \mathrm{mg}$, orally, $30 \mathrm{~min}$ before subarachnoid block was administered. Group II received only routine premedication. After starting an $i v$ line and preloading with $10 \mathrm{ml} \cdot \mathrm{kg}^{-1}$ crystalloid, patients were given $0.5 \%$ heavy bupivacaine 3.2 to $3.6 \mathrm{ml}$, depending on body weight, intrathecally. Patients with decreases in blood pressure of $20 \%$ were given ephedrine $\dot{N}$, in increments, in addition to crystalloids. Despite a similar level of block $\left(T_{3}-T_{4}\right)$ and iv fluids, the total dose of ephedrine supplement in Group I was $4.3 \pm 4.8 \mathrm{mg}$ compared with $11.6 \pm 9.4 \mathrm{mg}$ in Group II $(P<0.01)$. Also, 55 patients in Group I required intraoperative inotrope supplement compared with 83 in Group II $(P<0.01)$. We conclude that oral ephedrine premedication is a simple and effective way of reducing the incidence of hypotension in patients undergoing lower abdominal surgery under subarachnoid block.

Cette étude vise à démontrer l'efficacité de l'éphédrine orale pour prévenir lhypotension consécutive à la rachianesthésie.

\section{Key words}

ANAESTHETIC TECHNIQUE: spinal;

ANAESTHETICS, LOCAL: bupivacaine;

COMPLICATIONS: hypotension;

PREMEDICATION: ephedrine;

SYMPATHETIC NERVOUS SYSTEM: pharmacology,

ephedrine.

From the Om Nursing Home, and TU Teaching Hospital,

Katmandu, Nepal.

Address correspondence to: Dr. S.K. Kafle, Department of Anaesthesia and Intensive Care, Royal Adelaide Hospital, North Terrace, S.A. 5000, Australia.

Accepted for publication 7th July, 1994.
Deux cents femmes ASA I et II soumises à une chirurgie abdominale basse sont réparties au hasard en deux groupes (n $=100$ par groupe). Elles reçoivent toutes la prémédication usuelle constituée de diazepam $10 \mathrm{mg}$ et de ranitidine $150 \mathrm{mg}$ au coucher et $90 \cdot \mathrm{min}$ avant lintervention. Les patientes du groupe I reçoivent en plus de l'éphédrine $30 \mathrm{mg}$ per os $30 \mathrm{~min}$ avant la rachianesthésie. Le groupe II ne reçoit que la prémédication usuelle. Après linstallation d'un abord veineux, et une charge initiale de cristalloïde de $10 \mathrm{ml} \cdot \mathrm{kg}^{-1}$, les patientes reçoivent en rachianesthésie de la bupivacaïne hyperbare 3,2 à 3,6 mil selon leur poids. Malgré un niveau d'analgésie $\left(D_{3}-D_{4}\right)$ et une charge de liquide identiques, la dose additionnelle d'éphédrine pour le groupe I est de 4,3 $\pm 4,8 \mathrm{mg}$ comparativement à $11,6 \pm 9,4 \mathrm{mg}$ pour le groupe $I I(P<0,01)$. Cinquante-cinq patientes du groupe I ont eu besoin d'un inotrope additionnel peropératoire, comparativement à $83 d u$ groupe II $(P<0,01)$. Nous concluons que l'éphédrine orale constitue une méthode simple et efficace permettant de réduire lincidence d'hypotension en chirurgie abdominale basse sous rachianesthésie.

Hypotension is a well known complication of subarachnoid block, especially following a mid- or high-level block. Several methods have been used in an attempt to prevent the problem but with varying results. ${ }^{2-6} \mathrm{Re}-$ cently, the role of crystalloid preloading has been challenged. 5,6 We could not find any literature describing the use of oral ephedrine, although parenteral routes have been described. ${ }^{2-4}$ Thus, this study was performed to determine the efficacy of oral ephedrine in preventing hypotension associated with spinal anaesthesia.

\section{Methods}

Two hundred female patients of ASA status I or II, scheduled to undergo elective lower abdominal surgery (abdominal hysterectomy, tuboplasty, ovarian tumour removal) were randomly divided into two groups. Patients with advanced cardiovascular disease, including poorly controlled hypertension, were excluded from the study. 
All patients received oral premedication consisting of diazepam $10 \mathrm{mg}$, ranitidine $150 \mathrm{mg}$ at bed time on the night before surgery, and also $90 \mathrm{~min}$ before surgery. Thirty to forty-five minutes before the subarachnoid block, Group I patients were also given ephedrine $30 \mathrm{mg}$, po with a little water. The anaesthetists were blinded to the medication. In all patients an $i v$ infusion of crystalloid was started in the preparation room about half an hour before the subarachnoid block, and $10 \mathrm{ml} \cdot \mathrm{kg}^{-1}$ fluid given. In the operating room subarachnoid puncture was made with a 26G Quincke point needle, using a paramedian technique, and 3.2 to $3.6 \mathrm{ml}$ heavy bupivacaine $0.5 \%$ were injected intrathecally, depending on the patient's body weight. Patients were then placed supine with a 5-10 $0^{\circ}$ head-down tilt.

Metoclopramide in a dose of $0.15 \mathrm{mg} \cdot \mathrm{kg}^{-1}$ was given to all patients after the block to reduce the incidence of retching and vomiting. In addition, all patients were sedated using diazepam $5 \mathrm{mg}$ and pentazocine $15 \mathrm{mg}, i v$.

Intraoperatively, any decrease in systolic blood pressure of $20 \%$ was treated with ephedrine $3-6 \mathrm{mg} i v$. This was repeated until the patient recovered completely from the subarachnoid block. Also, intravenous fluids (crystalloid) were infused rapidly to treat the hypotension.

Student's $t$ test was used to compare the total dose of ephedrine used, and a Chi square test to compare the number of patients requiring treatment. $P<0.05$ was considered to be statistically significant.

\section{Results}

The demographic data showed the two groups were similar with respect to age, height, and weight (Table I).

Despite a similar level of sensory block, up to $T_{3}-T_{4}$, and a similar amount of fluid therapy (2516.4 \pm 533 $\mathrm{ml}$ and $2463.4 \pm 591.6 \mathrm{ml}$ in Groups I and II respectively), patients in Group I (ephedrine group) received less ephedrine supplement than those in Group II and fewer patients in the ephedrine group required treatment (55 compared with 83) $(P<0.01)$ (Table II).

The intraoperative heart rate was similar in the two groups ( $92 \pm 7.7$ vs $91 \pm 9.8$ beats $\cdot \min ^{-1}$ ).

\section{Discussion}

The aim of this study was to show the efficacy of ephedrine when given orally. It was thought that if this route proved to be effective, it could become one of the simplest ways of preventing hypotension which is one of the commonest complications of central neuraxial blockade.

Ephedrine is one of the most commonly used drugs in the treatment of hypotension during spinal anaesthesia. It stimulates both $\alpha$ and $\beta$ receptors and also releases norepinephrine from sympathetic neurons. ${ }^{1}$ It is also effective after oral administration. It used to be the drug
TABLE I Demographic data (mean \pm SD)

\begin{tabular}{lcc}
\hline & Group I & Group II \\
\hline Age (yr) & $37.2 \pm 8.3$ & $36.8 \pm 9.3$ \\
Height $(\mathrm{cm})$ & $156.4 \pm 5.1$ & $157.6 \pm 4.6$ \\
Weight $(\mathrm{kg})$ & $54.5 \pm 9.9$ & $51.8 \pm 10.48$ \\
\hline
\end{tabular}

TABLE II Intraoperative inotrope supplement

\begin{tabular}{lll}
\hline Group & $\begin{array}{l}\text { Ephedrine } \\
(m g \pm S d)\end{array}$ & $\begin{array}{l}\text { No. of patients } \\
\text { not requiring } \\
\text { treatment }\end{array}$ \\
\hline I & $4.3 \pm 4.8$ & 45 \\
II & $11.6 \pm 9.4$ & 17 \\
$P$ & $<0.01$ & $<0.01$ \\
\hline
\end{tabular}

of choice for the treatment of obstructive pulmonary diseases for the same reason. The onset of action following oral administration is $30-45$ min and the effect lasts for three to five hours.

The administration of ephedrine via any route causes an increase in blood pressure, tachycardia, and bronchodilatation. It also stimulates the central nervous system. Tachyphylaxis may decrease its effectiveness after repeated use. Our results show that oral ephedrine given 30-45 min before to subarachnoid block is effective in reducing the incidence of hypotension.

In addition, we observed that oral ephedrine was effective in patients whose hypertension was controlled with $\beta$-blockers; none had an undesirable rise in blood pressure perioperatively. However, the safety of this technique in such patients and also in patients with mild, untreated hypertension, requires further study.

Tachycardia did not occur in any of the patients in the oral ephedrine group, although tachycardia did occur in patients given intravenous ephedrine to treat the hypotension.

None of the patients in the pretreated group was found to be excitable or restless.

We conclude that oral ephedrine, given $30-45 \mathrm{~min}$ before surgery, is a simple and effective method of reducing the incidence of hypotension during spinal anaesthesia. We suggest that it is an acceptable alternative to other techniques used for this purpose in ASA I or II patients.

\section{Acknowledgements}

We are thankful to Drs. Bhola Rijal and Suphatra Koirala, consultant gynaecologist and obstetrician for their cooperation. We are also thankful to all the nursing staff. Finally, we would like to thank Mrs. Shanta Khakurel for her help in many different ways. 


\section{References}

1 Brian $B H$, Robert $J L$. Cathecholamine and sympathomimetic drugs. In: Goodman AG (Ed.). Goodman and Gilman's The Pharmacological Basis of Therapeutics, 8 th ed. Singapore: Maxwell MacMillan, 1990; 213-4.

2 Hemmingsen C, Poulsen JA, Risbo JA. Prophylactic ephedrine during spinal anaesthesia: double-blind study in patients in ASA groups I-III. Br J Anaesth 1989; 63: 340-2.

3 Rolbin SH, Cole AFD, Hew EM, Pollard A, Virgint S. Prophylactic intramuscular ephedrine before epidural anaesthesia for Caesarean section: efficacy and actions on the fetus and newborn. Can Anaesth Soc J 1982; 29: 148-53.

4 Gajraj NM, Victory RA, Pace NA, van Elstraete AC, Wallace $D H$. Comparison of an ephedrine infusion with crystalloid administration for prevention of hypotension during spinal anaesthesia. Anesth Analg 1993; 76: 1023-6.

5 Coe AJ, Revanas $B$. Is crystalloid preloading useful in spinal anaesthesia in the elderly? Anaesthesia 1990; 45: 241-3.

6 Rout CC, Akoojee SS, Rocke DA, Gouws E. Rapid administration of crystalloid preload does not decrease the incidence of hypotension after spinal anaesthesia for elective Caesarean section. Br J Anaesth 1992; 68: 394-7. 